\title{
Evaluation of Stope Stability in Underground Mine; Hermyingyi (Sn-W Deposit) Mine in Myanmar
}

\section{Cho Thae 0o1,2, Takashi Sasaoka1, Hideki Shimada1, Akihiro Hamanaka1, Tun Naing³, Dyson Moses ${ }^{1}$}

\author{
${ }^{1}$ Department of Earth Resources Engineering, Kyushu University, Fukuoka, Japan \\ ${ }^{2}$ Department of Geology, Kyaing Tong University, Kyaing Tong, Myanmar \\ ${ }^{3}$ Department of Geology, Yangon Technical University, Yangon, Myanmar \\ Email: chothaeoo@gmail.com, sasaoka@mine.kyushu-u.ac.jp, shimada@mine.kyushu-u.ac.jp, hamanaka@mine.kyushu-u.ac.jp, \\ tunnaing1972@gmail.com, moses18r@mine.kyushu-u.ac.jp
}

How to cite this paper: Oo, C. T., Sasaoka, T., Shimada, H., Hamanaka, A., Naing, T., \& Moses, D. (2021). Evaluation of Stope Stability in Underground Mine; Hermyingyi (Sn-W Deposit) Mine in Myanmar. Journal of Geoscience and Environment Protection, 9, 107-120.

https://doi.org/10.4236/gep.2021.91009

Received: December 25, 2020

Accepted: January 26, 2021

Published: January 29, 2021

Copyright $\odot 2021$ by author(s) and Scientific Research Publishing Inc. This work is licensed under the Creative Commons Attribution International License (CC BY 4.0).

http://creativecommons.org/licenses/by/4.0/

(c) (i) Open Access

\begin{abstract}
The stability of underground excavations has become an important issue in order to extend underground mining operations and extract deeper deposits. The increasing demand for Tin-Tungsten (Sn-W) for industry and its market price has created a motivation for mining companies to extract deep-seated $\mathrm{Sn}-\mathrm{W}$ ore deposits in Myanmar. Thus, this paper aims to investigate the stability of underground openings, especially, the stope with considering the mining methods. To meet the objective, FLAC ${ }^{3 \mathrm{D}} 5.0$ simulation was used for the assessment of stope under different stress ratios, $0.5,1.0$, and 1.5 for two types of underground mines; Open stoping and Cut and Fill stoping. The results show that the risk of instability of stope is high under the stress ratio of $K=0.5$ than that of $K=1.0$ and $K=1.5$ in both mining methods. However, the stability of the stope in open stope method is lower than that of cut-and-fill method obviously. This result shows that the appropriate mining method has to be selected for extraction of Sn-W deposit carefully in terms of the balance of safety and cost.
\end{abstract}

\section{Keywords}

Sn-W Deposit, Stress Ratio, Open Stope, Cut-and-Fill Stope, FLAC $^{3 D}$ Simulation

\section{Introduction}

The stability of underground excavations has become an important issue in the 
underground mining operation due to mine enlargement and excavation of deeper mineral resources (Sasaoka et al., 2015). Open stoping and cut-and-fill method are commonly used as underground mining methods in Myanmar because the ore body, which is from primary source, is located at a considerable depth, especially at the Hermyingyi (W-Sn) deposit mine. However, the application of open stope and cut-and-fill methods for underground mining generally encounter failures due to the geological structure and high regional stress condition. Although the stoping method is cardinally influenced by environmental effects related to the induced stress of natural conditions and the structure of geometry, the quartz-vein type is a typical $(\mathrm{Sn}-\mathrm{W})$ deposit in this study area. Therefore, controlling stope stability is crucial, not only for the safety of the mineworkers and transportation of equipment but also for the capacity of mine production capacity and profitability by minimizing unexpected ore body suspension.

Various research works on underground mining have focused on the interaction between underground openings. For instance, Purwanto et al. (2013) studied the influence of the stope design on hanging wall decline stability under multiple excavation. The study revealed that weakening rock mass condition can lead to the intitiation of instability. In relation to stress, the effects of large-scale stress adjustment and redistribution, hysteretic backfill, low strength of filling body, unfilled void space, as well as repeated mining activities were studied and showed that the conditions concurrently caused ground deformation (Zhao, Ma, Zhang, \& Guo, 2013; Sepehri, Apel, \& Liu, 2017). However, very few researches and publications are found on the influence of in situ stress conditions on the stability of open excavation in a comparative approach.

Since the stability of mine openings depends on the mining method, induced stress, geology, and trend of the vein in the ground, numerical assessment has shown to be helpful to understand the situation of stability in the stoping area. In this study, the unstable displacement and the factor of safety of the stope are calculated with different stress ratios; $0.5,1.0$, and 1.5 because the regional stresses are high around this area, which could potentially control stability conditions at Hermyingyi (Sn-W) deposit mine. Thus the paper discusses the stability of underground openings, especially, the stope beside of excavation area in different mining methods and mining conditions.

\section{Location and Geology of the Study Area}

\subsection{Location}

The study area (Latitude $14^{\circ} 14^{\prime} \mathrm{N}$, longitude $98^{\circ} 21^{\prime} \mathrm{E}$ ) is located approximately 40 $\mathrm{km}$ northeast of Dawei Township, Thanintharyi Division, Southern Part in Myanmar shown in Figure 1. In general, the geology of Myanmar is shaped by the complex ongoing tectonism characterized by the mobile belts shown in Figure 1 .

\subsection{Stratigraphy and Mineralogy}

The sequence of rock units at the study site is less complex. The host rock in the 


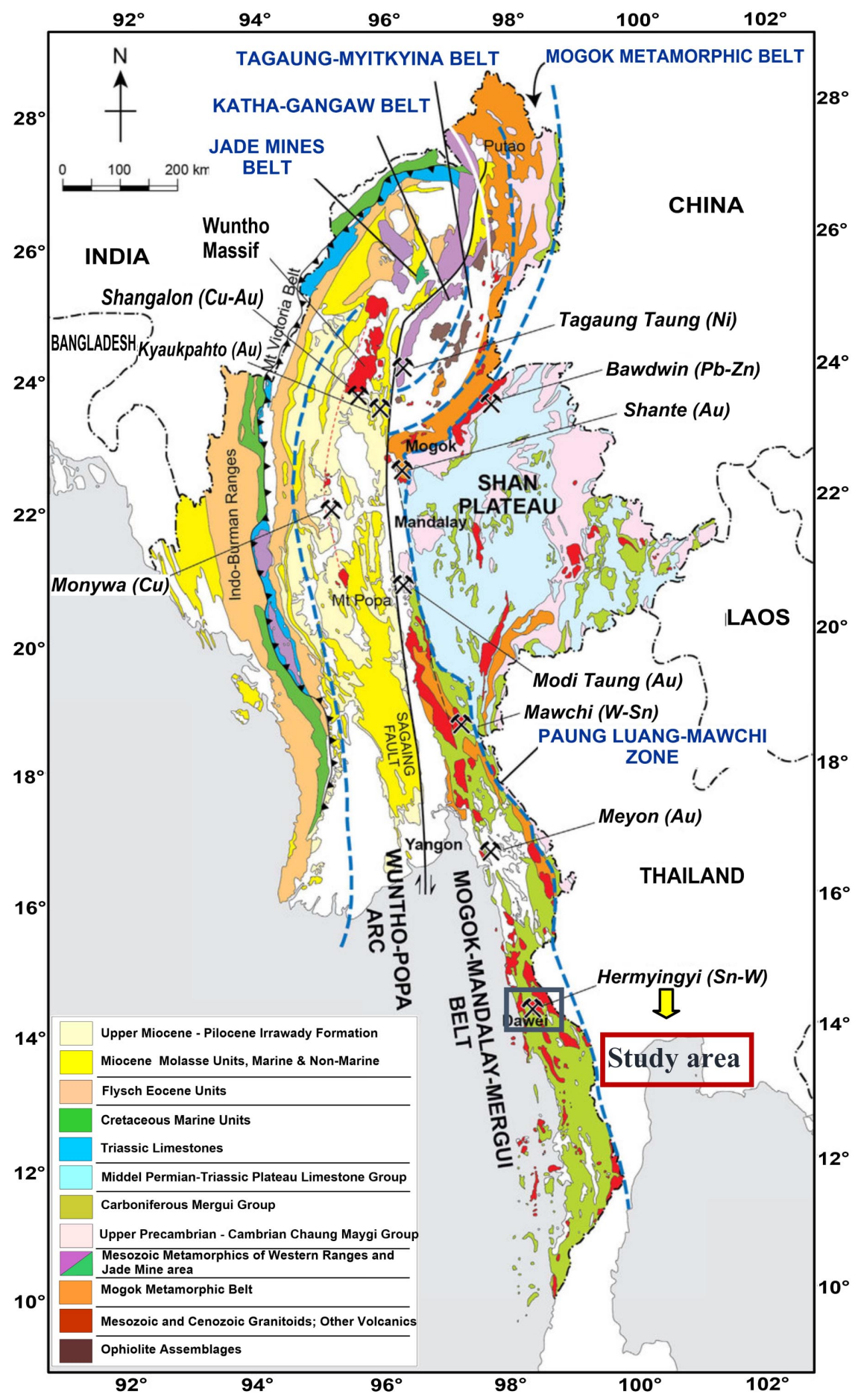

Figure 1. Showing the location of the study area and geological map mention major blocks, major Sn-W deposits, and the granitoid belts Myanmar (After (Zaw, 1990)).

region is unfossiliferous metasedimentary of Mergui series group (Mitchell, Chung, \& Oo, 2013). The unit belongs to the Upper Carboniferous to Lower Permian age.

Figure 2 shows that the rock strike has NNW-SSE orientation with steep easterly dips of $75^{\circ}-85^{\circ}$, although some west veins are occasionally noted. The 


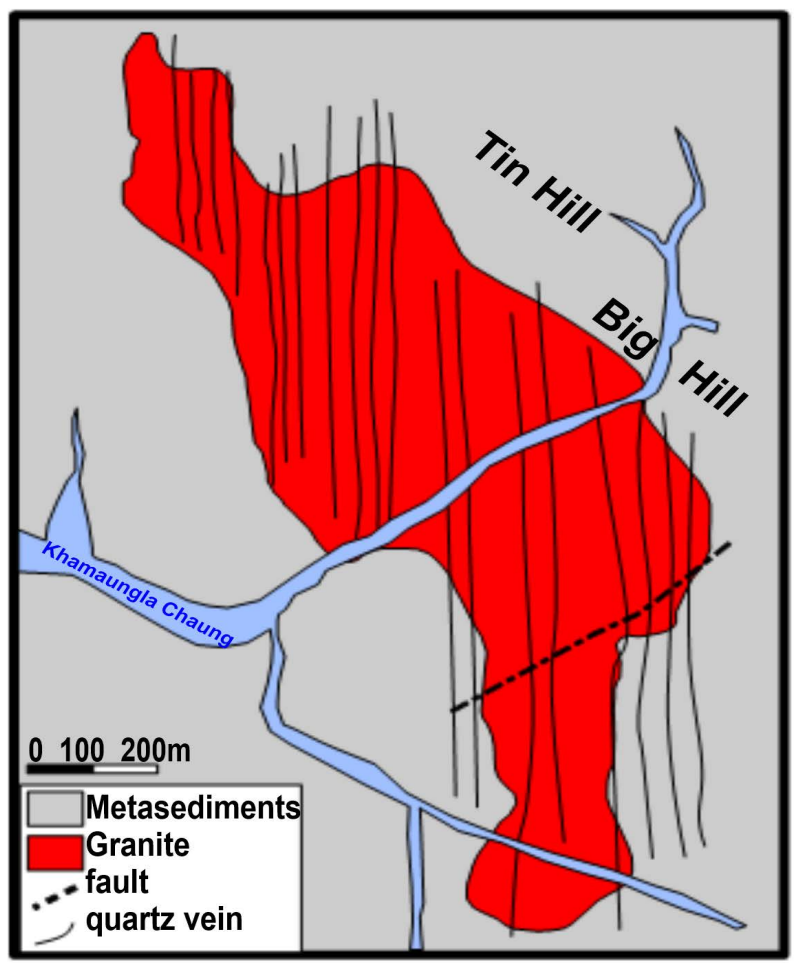

Figure 2. Detail geological map of the Hermyingyi Mine and the main Sn-W vein system simplified after Bender (1983).

thickness of quartz veins is discovered to be above $2 \mathrm{~m}$, which contains the following ore assemblage (Htun, Htay, \& Zaw, 2017): wolframite, cassiterite, molybdenite, pyrite, sphalerite, chalcopyrite, galena, bismuthinite, and bismuth. Some veins have been studied to extend over $200 \mathrm{~m}$ in length (Htun et al., 2017; Bender, 1983) and are dominated by very thick intervals of argillaceous with minor limestone, quartzite, and volcanic detritus. The work of Jiang et al. (2019) reveals that Hermyingyi area is composed of plagioclase, quartz, muscovite, K-feldspar and biotite. Htun et al. (2017) further explain that there are 300 major prospected veins of which 40 branches into Hermyingyi mine area. At present, there are only 15 major productive ore veins. Tin-tungsten mineralization is mainly hosted in quartz veins and occurs along the exo- and endo-contacts of granites, at the apical zones of granitoid intrusions, or in the adjacent sedimentary rocks (Defant \& Drummond, 1990).

\subsection{Structural Setting}

The major fault in the area was cut across the ore body. Besides, the minor faults and joints predominate in the ground. The mineralized veins lie parallel inclined to the mine area. Therefore, the structures have an obvious impact on the mine environment. On the other hand, tectonism is active near the mine site. Moreover, the study area is located beside the coastal region where the initial stress is influenced by the underground mine of the study area. Figure 3 shows the roof collapse that occurred in the study area. 


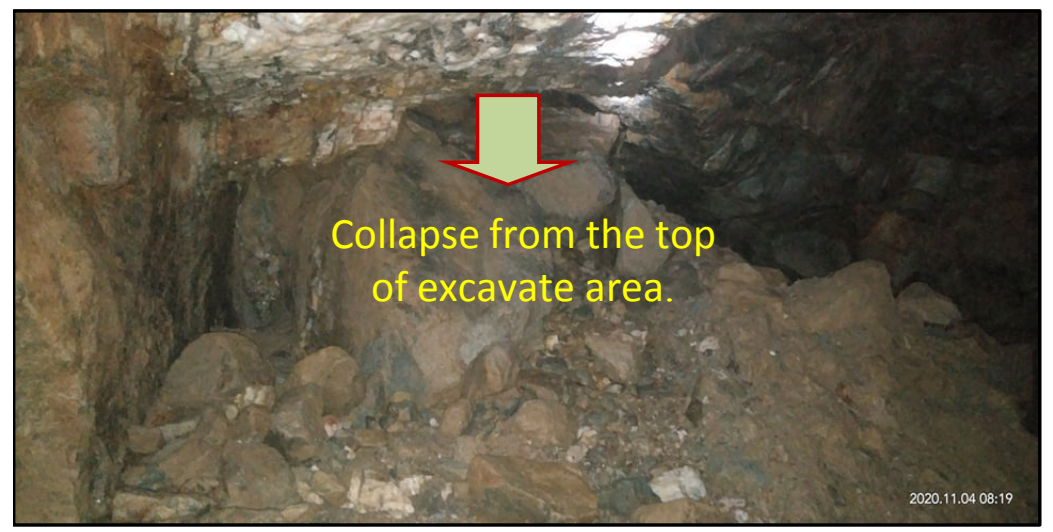

Figure 3. Roof failure occurred at the B-load vein in Hermyingyi (Sn-W) deposit mine.

\subsection{Mine Planning and Objective}

The development of the mine area is located at level 1 as shown with a blue boundary line in Figure 4(a), at the Hermyingy (Sn-W) deposit. The mining method being used currently in the underground open stoping method, especially considering that the ore is extracted from the primary veins. On the other hand, in some sections, open-pit and open-cut methods are used where placer deposit, eluvial types of material were observed beside of level 1 . This paper is focused on level 1 for parallel inclined veins as shown in Figure 4(b). The objective of the study is to evaluate the potential of the instability of the stope under ongoing mining operations at $\mathrm{Sn}-\mathrm{W}$ deposit mine and propose the guidelines for the safe mining operation.

\section{Numerical Simulation}

Since the study aims to understand the stability of the stope in the underground mine, as recommended by Yasitli \& Unver (2005), three-dimension (3-D) models are used for this study. A numerical model was created in the finite difference method (FDM) using FLAC ${ }^{3 D} 5.0$ software for analyzing the stability of open stope at underground and compared with that of cut-and-fill method. The dimensions of the model extend $240 \mathrm{~m}$ in height, $150 \mathrm{~m}$ in length, and $150 \mathrm{~m}$ in width, and the vein angle is $80^{\circ}$ (see Figure 5). The front of the model height is $190 \mathrm{~m}$, and the upper part of the model has an inclined slope angle of $36^{\circ}$. The boundary of the Z-direction is free at the top, and the bottom of the Z-direction is fixed. All vertical boundaries along $\mathrm{X}$ and $\mathrm{Y}$ directions are fixed, whereas the gravitational stress is applied. The host rock types are set up in FLAC ${ }^{3 \mathrm{D}}$ simulation such as Foot wall (granite), Hanging wall (Limestone), and vein (quartzite), respectively.

The study area is in the mountainous region. Thus, the model is created to represent the actual mine plan at Hermyingyi (Sn-W) deposit mine. In order to evaluate the stability of the stope, the factor of safety based on Mohr-Coulomb failure criterion, is used in elasto-plastic state. Based on this criterion, the condition of the stope is categorized as a failure when the extent of failure proximity is 


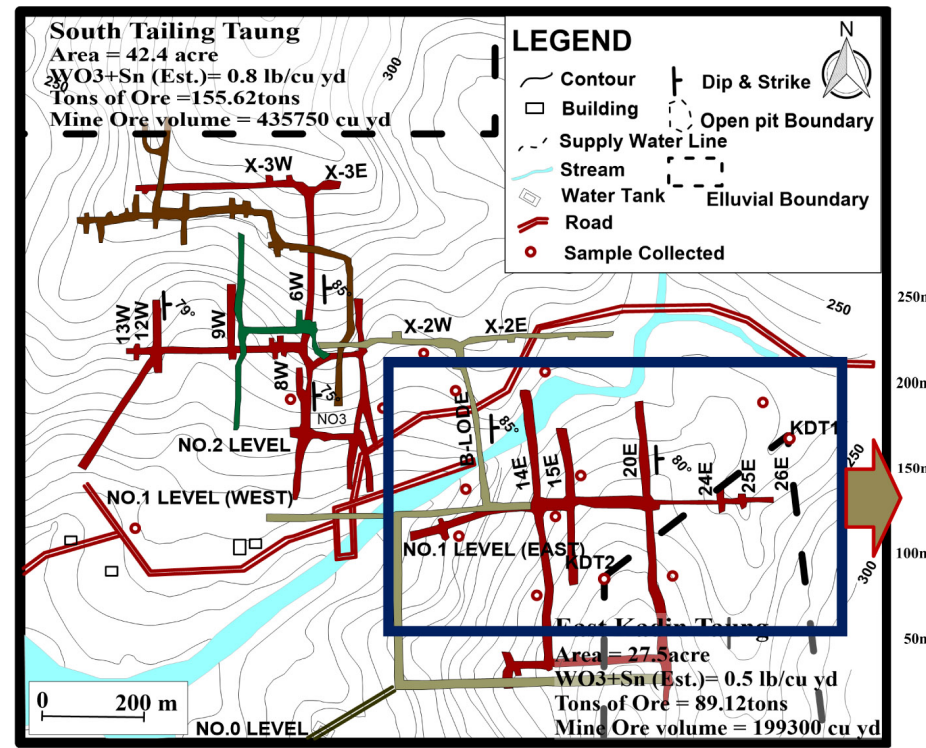

(a)

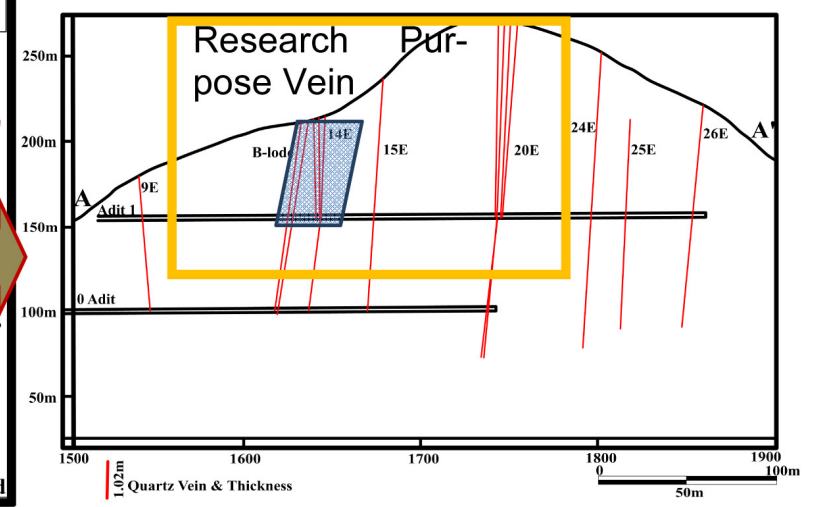

(b)

Figure 4. (a) The overview planning of Mine-out area (modified after Aung Tun Oo, 2018, unpublished); and (b) Systematic diagram of mineral vein section-looking east, a cross-section along (A-A') at Hermyingyi (Sn-W) deposit mine (modified after Aung Tun Oo, 2018, unpublished).

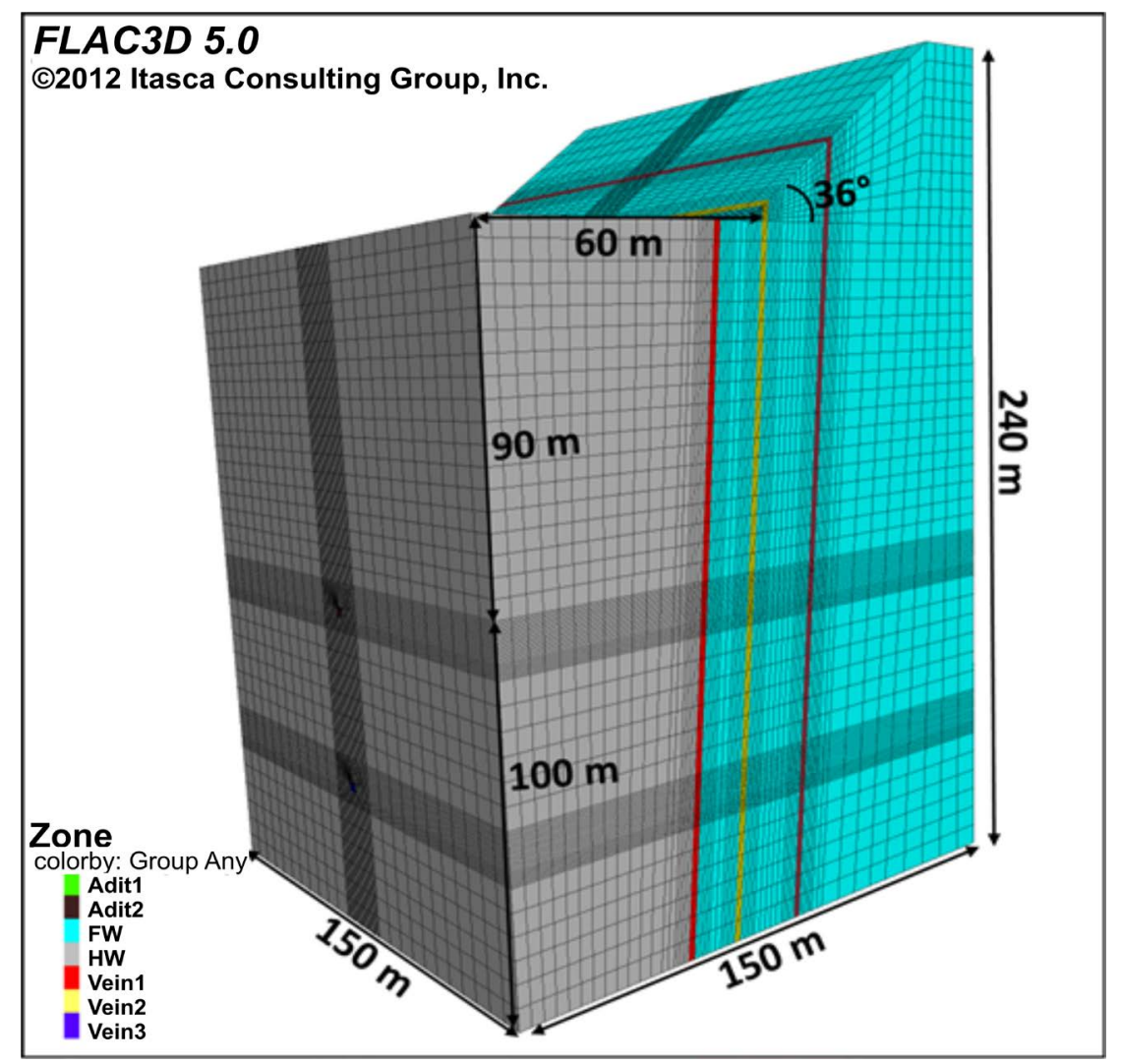

Figure 5. Mohr-Columb constitutive model by FLAC3D.

$\geq 1.3$ because it is a temporary mine opening (Hoek \& Brown, 1980; Hoek, Kaiser, \& Bawden, 1993). The equation of the factor of safety is applied as follows: 


$$
\mathrm{FS}=\frac{\text { Rock Strength }}{\text { Induced Stress }}=\frac{c \cos +\frac{\sigma_{1}+\sigma_{3}}{2} \sin \phi}{\frac{\sigma_{1}+\sigma_{3}}{2}}
$$

(Eberhardt, 2012). where, FS is the factor of safety, $\sigma_{1}$ is the maximum principal stress, $\sigma_{3}$ is the minimum principal stress, $\phi$ is the friction angle, and $\mathrm{c}$ is the cohesion.

In order to determine the mechanical properties of rocks, a series of laboratory tests were conducted by using rock samples obtained at the mine site. The mechanical property data are shown in Table 1.

\section{Excavation Sequences}

Two types of underground methods are evaluated in this paper: 1) Open stop method which is currently used and 2) cut-and-fill method. Figure 6(a) shows

Table 1. Mechanical properties of rock and filling material (waste rock).

\begin{tabular}{ccccc}
\hline Parameter & Granite, FW & Limestone, HW & Vein & Filling material \\
\hline Uniaxial Compressive Stress, MPa & 0.037 & 0.020 & 0.026 & - \\
Young's Modulus, GPa & 8.0 & 3.0 & 3.0 & 0.15 \\
Poisson's ratio & 0.22 & 0.23 & 0.23 & 0.32 \\
Friction Angle, deg. & 42 & 38 & 39 & 21 \\
Cohesion, $\mathrm{MPa}$ & 0.59 & 0.50 & 0.51 & 0.20 \\
\hline
\end{tabular}

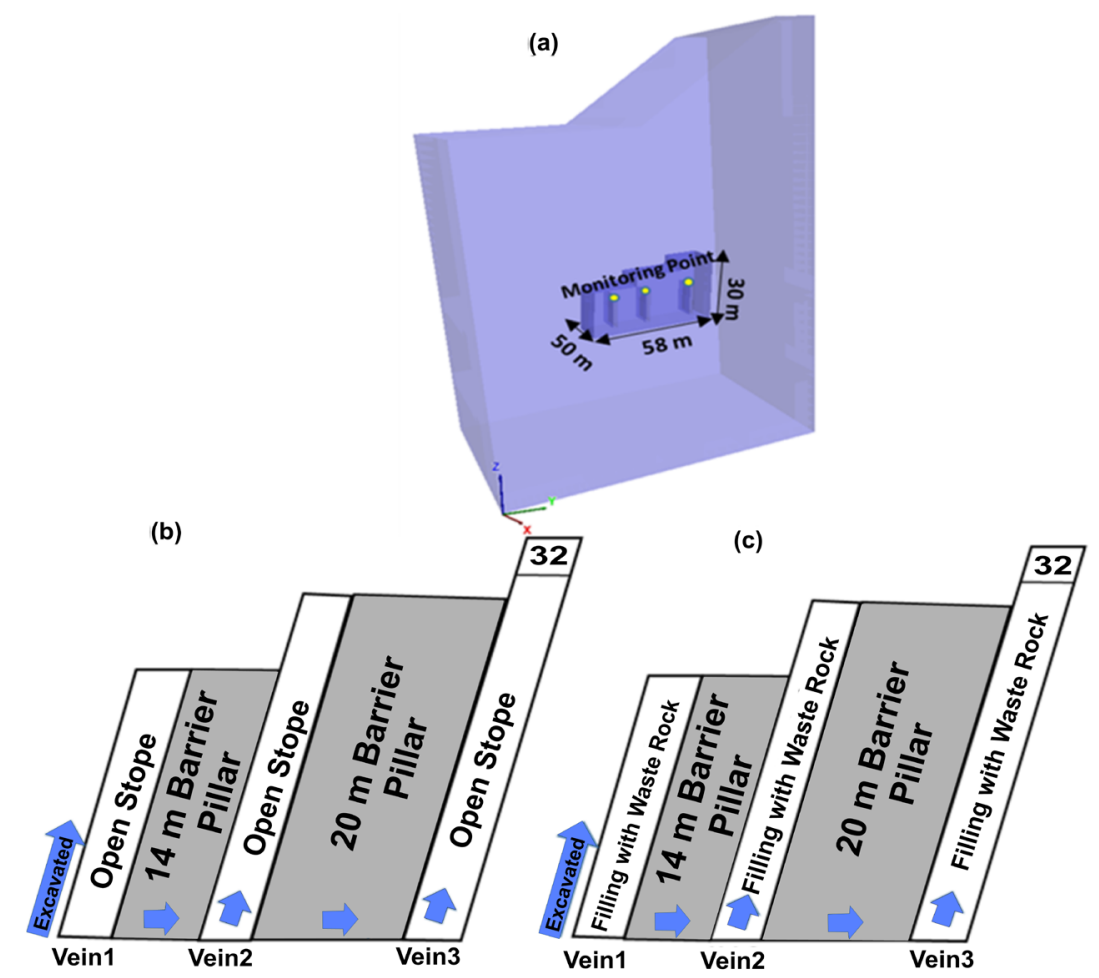

Figure 6. Systematic diagram for excavation: (a) Created the mine-out area; (b) Open stop method; and (c) Cut-and-fill stoping method at the Hermyingy (Sn-W) deposit mine. 
the mine excavated area is located $150 \mathrm{~m}$ in depth from the surface as conducted in FLAC ${ }^{3 \mathrm{D}}$. Figure 6(b) presents the open stop technique. The stope dimension is $30 \mathrm{~m}$ in length, $5 \mathrm{~m}$ in width, and $2 \mathrm{~m}$ in height.

The excavation steps are 32 steps for all veins. The pillar measuring $14 \mathrm{~m}$ is left between vein 1 and vein 2 , and $20 \mathrm{~m}$ between vein 2 and vein 3 . Their barrier pillar is different width due to the consideration of safety for stope stability and development of the vein system in the mine. In the post excavation the stopes are free space not filled with any material.

Figure 6(c) shows the cut-and-fill stoping method. The first step is excavated from the lower stope to the final stope, it is 8 steps and then continuously excavate to the second vein with similar excavation pattern as the previous one totaling 11 steps. In the third vein, 13 steps are used in the same way to excavate in order to meet the objective. This method is used to fill material after excavating stope before progressing to the next step. The monitoring points are pinned above each stope to evaluate prevailing conditions. The key aspect of the paper is to determine the failure initiation and progression when excavating at the three parallel inclined veins under different stress ratios.

\section{Results and Discussions}

While the essence of evaluation in this study is to determine the stability with the strength-to-stress interaction, it is generally acknowledged that higher stress develops in the roof of the intersection of the mine out area. Therefore, the different stress ratios, $K(0.5,1.0,1.5)$ are used to analyze the stability of open stope and cut-and-fill stope. The ratio between the horizontal and vertical stress is referred to as $K$-ratio which is mathematically presented as;

$$
k=\frac{\sigma_{h}}{\sigma_{v}}
$$

(Brown \& Hoek, 1978).

\subsection{Factor of Safety}

The factor of safety determination is vital at the ongoing mined out area. Figure 7 presents two cases that are compared in which the open stope method and the cut-and-fill method are under different stress ratios, $K=0.5,1.0,1.5$. According to the results, it can be said that the stability around the stope is low at $K=0.5$. The trend of FoS dramatically increased under stress ratio, 0.5 in both cases. In comparison with open stope and cut-and-fill methods under stress ratio, $K=0.5$ : the open stope is shown in Figure 7(a). The FoS value, in this case, is 0.9 where the instability is expansive around the excavated area, whereas the first stope of Hanging wall and the third stope of Foot wall failure is observed at $9-11 \mathrm{~m}$ in width. Moreover, the failures appear to have occurred around the pillar in all stopes. Calculating the step by step of the stope, the failure is found at the crown pillar for each stope. On the other hand, in the Cut and Fill stope, FoS value is 1.35. Based on the results, the failure zone is developed around the first and the 

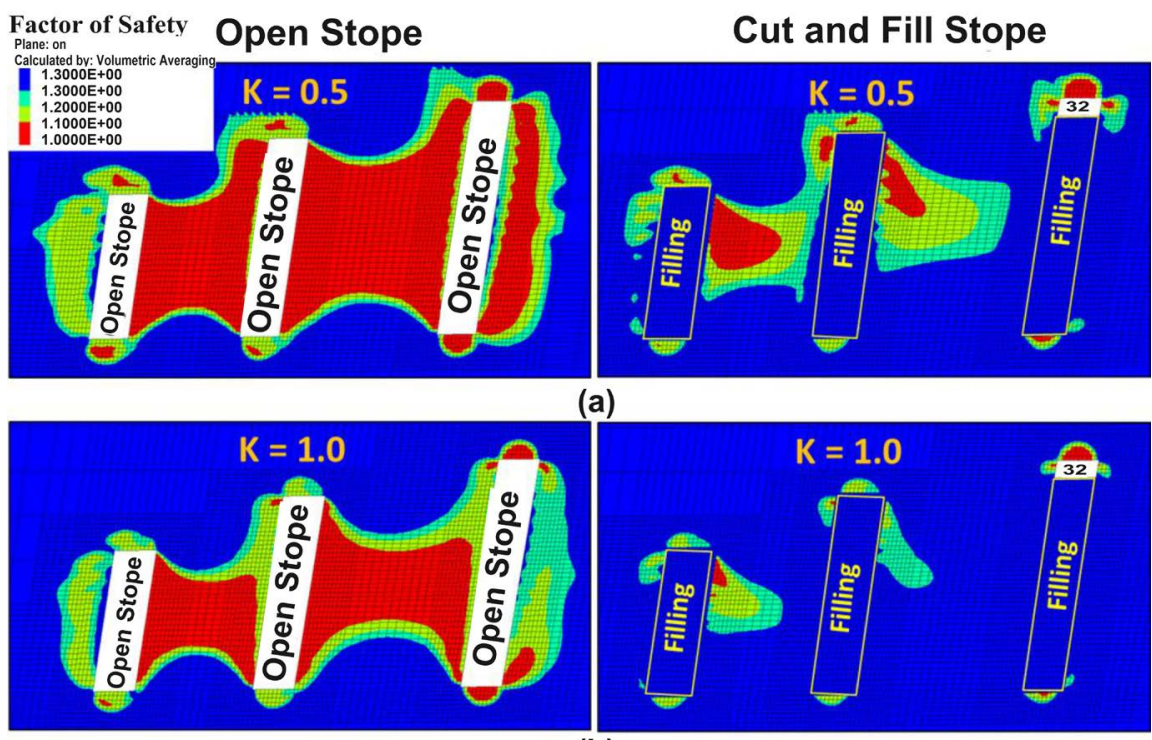

(b)
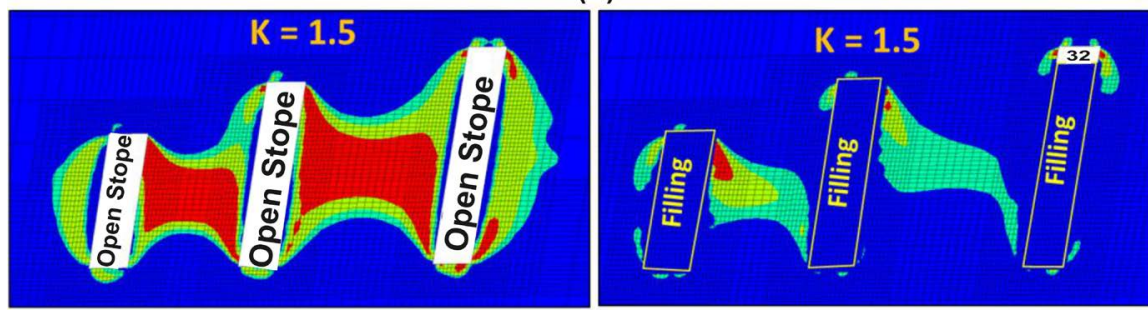

(c)

Figure 7. Demonstrated the result of FoS in the study area (a) stress ratio, $K=0.5$, (b) stress ratio, $K=1.0$, and (c) stress ratio, $K=1.5$.

second stopes, and the stability of the barrier pillar decrease due to the connecting failure zone. The third stope is not much affected but the failure of the crown pillar. Hence, it can be said that the application of the cut-and-fill method can improve the stability of the stope obviously, but $20 \mathrm{~m}$ or more thicker barrier pillar should be left for safe operation under the stress ratio of $K=0.5$.

Figure 7(b) shows the stress ratio, $K=1.0$. Comparing the two types of mining methods: the results show that the FoS value is 1.1 for the open stope and 1.45 for the cut-and-fill stope. The failure appears to have developed at $5-6 \mathrm{~m}$ thickness in the hanging wall of the first stope and the Foot wall of the third stope under open stope versus $3-4 \mathrm{~m}$ thickness in the hanging wall of the first stope and the Foot wall of the third stope under cut-and-fill stope. The failure of the barrier pillar appears connected with all stope in the open stope method but the cut-and-fill method is not connected. Hence, it can be said that the application of the cut-and-fill method can maintain the stability of stopes, and $14 \mathrm{~m}$ or less barrier pillar is enough for safe operation under the stress ratio of $K=1.0$.

Figure 7(c) presents the results of $K=1.5$. The FoS in the case of the open stope is 1.3 and that of the cut-and-fill stope is 1.5 . The stability of the stope increase with increasing the stress ratio. The comparative trend of stability for the two methods, based on FoS, is Figure 8. From the outcomes, it can be deduced 


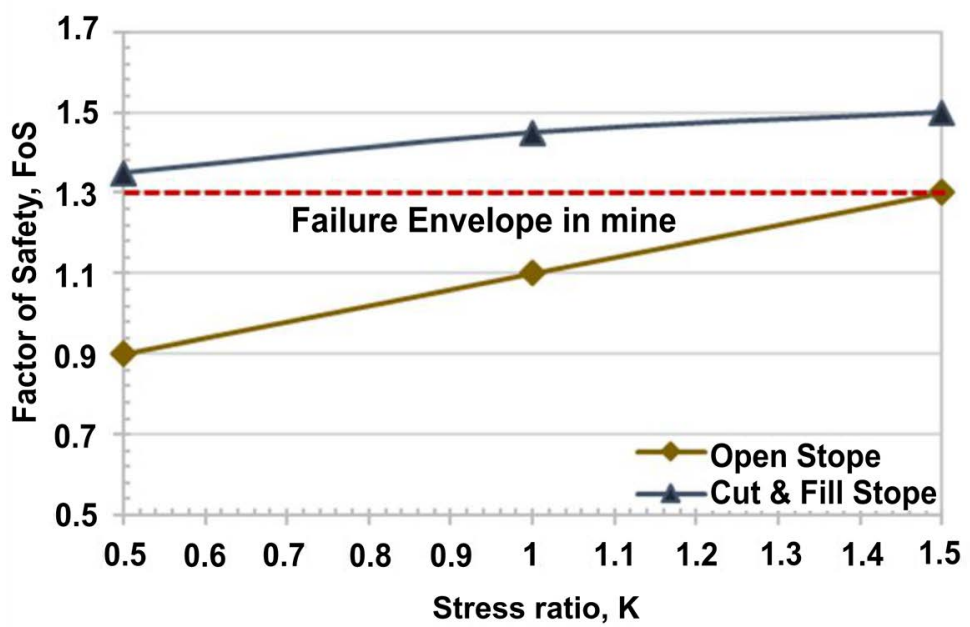

Figure 8. Comparison of the FoS with open stope method and cut-and-fill method.

about the Sn-W deposit that the open stope method has increased risk of instability as reflected in the FoS, which is below the benchmarked value of 1.3. Thus, it can be concluded that the application of the cut-and-fill method and/or width of the barrier pillar should be considered carefully based on the in-situ stress conditions.

\subsection{Displacement}

Mining activities induce volumetric as well as stress-strain changes in the rock mass. Once deformation surpasses the limits controlled by the rock strength, instability is generated on the mining excavation. To manage unprecedented failures, it is crucial to record the stability of rocks surrounding the stopes. Unlike when mining operations are in progress where monitoring is carried out periodically and sometimes automatically using reference points, at the simulation level, this was achieved by pinning monitoring points on strategic positions.

Measuring displacement at the underground ongoing mine revealed risky conditions against failure. The contours of Y-displacement are shown in Figure 9. The contour line shows that the displacement value is increased if the contour scale is small. From Figure 9(a) the minimum Y-displacement of the open stope is $40 \mathrm{~mm}$ and the cut-and-fill stope is $31 \mathrm{~mm}$ at the stress ratio, $K=0.5$ as monitored around the Foot wall. Besides, the maximum Y-displacement of the open stope is $46 \mathrm{~mm}$, and the cut-and-fill stope is $37 \mathrm{~mm}$, these results are recorded in the hanging wall. All the results are based on the final excavation step of 32 .

Figure 9 (b) shows the displacement results at stress ratio, $K=1.0$. The results demonstrate that the maximum Y-displacement is $31 \mathrm{~mm}$ based on open stope, $25 \mathrm{~mm}$ based on cut-and-fill stope, moreover, the minimum Y-displacement is $27 \mathrm{~mm}$ for open stope and $21 \mathrm{~mm}$ for cut-and-fill stope.

Figure 9(c) presents the displacement conditions at stress ratio, $K=1.5$. The outcome indicates that the maximum Y-displacement is $18 \mathrm{~mm}$ for open stope and $14 \mathrm{~mm}$ in cut-and-fill stope and the minimum Y-displacement is $16 \mathrm{~mm}$ for 

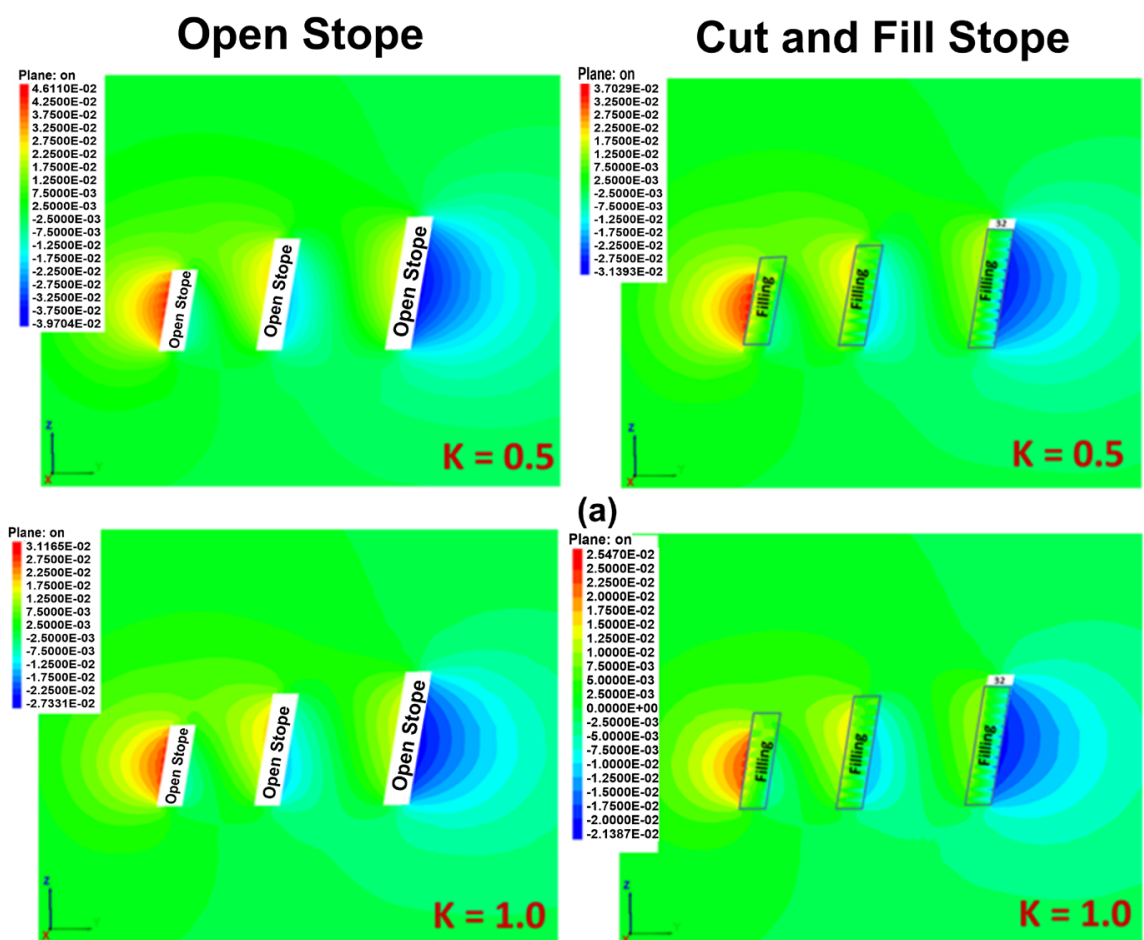

(a)
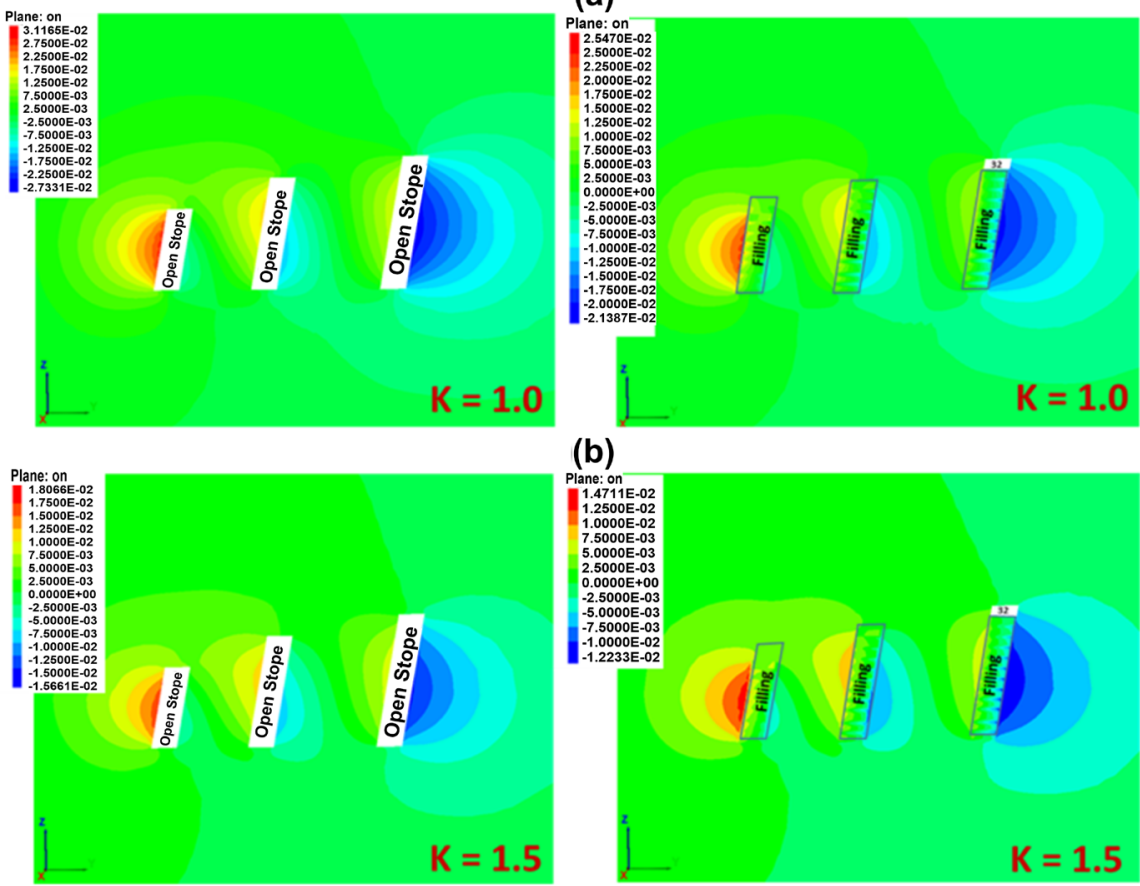

(b)

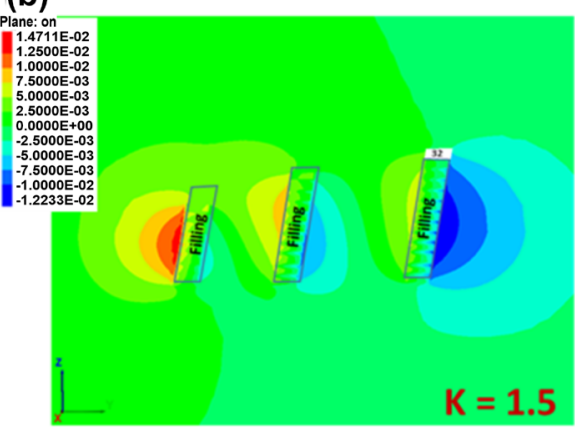

(c)

Figure 9. Displacement results in the study area (a) stress ratio, $K=0.5$; (b) stress ratio, $K$ $=1.0$; and (c) stress ratio, $K=1.5$.

open stope and $12 \mathrm{~mm}$ for cut-and-fill stope method. After comparing the outcome, the Y-displacement is exactly increasing around the stope in the open stope relative to the cut-and-fill stope. These displacement findings are in agreement with a study by (Sepehri, Apel, \& Liu, 2017) who showed that the horizontal stress to vertical stress ratio has a significant impact on the development and propagation of the relaxation and yielding zones around underground openings such that under smaller gravitational loading the relaxation increases leading to reduced impact of yielding. Therefore, the result should be considered for the excavation in the adjacent of mine-out area.

The results of displacement correlate well with the stress direction as presented in Figure 10. The head of the stress direction is dipping into the excavated area and maximum stress came from the Hanging wall of the first vein and the Foot wall of the third vein, but the second vein has minimal stress concentration relative 


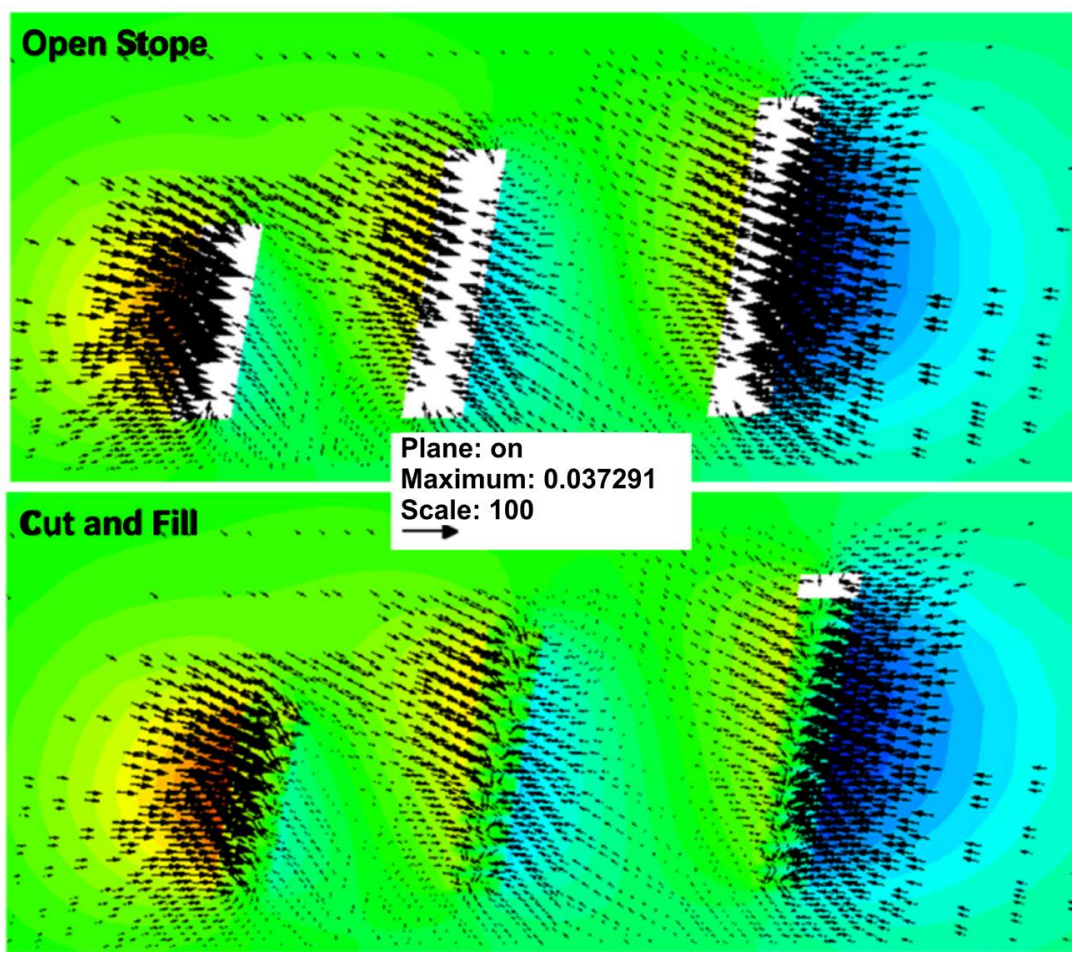

Figure 10. Stress distribution of the stope surrounding the stope in the underground.

to the two veins. Furthermore, a comparison of the two methods, the rocks surrounding the stopes show a significant risk of collapse into the stope under the open stope method, but the cut-and-fill method can be controlled for the collapse of the surrounding rock mass of stope.

\section{Conclusion}

In this study, the potential of the instability of underground mine stope in two mining methods, namely, open stope and cut-and-fill stope has been investigated. Based on the results of a series of numerical simulations, it can be concluded that the in-situ stress condition and barrier pillar width have an obvious impact on the stability of the stope. Moreover, the backfilling of the stope also improves the stability of the stope dramatically. According to the results, although open stope was adopted at the Hermyingyi (Sn-W) deposit mine in the current mining operation, the application of the cut-and-fill method is one of the effective options for developing the underground mine in deeper Sn-W deposits. Since the study only focused on the influence of in situ stress on stability of the stope, further analyses are recommended to understand the effect of rock mass degradation and structural controls like fault and joints in the ongoing mine out area in order to ascertain the superiority of cut-and-fill method over open stope for adoption.

\section{Acknowledgements}

The authors would like to thank Japan International Cooperation Agency 
(JICA), KIZUNA program for financial support. And, the authors deeply thank Kyaw Naing Htoo, Manager, Hermyingyi mine, and La Naing Oo, Mining Geologist for the support concerning with collection of samples and reference data of Hermyingyi mine during the research study.

\section{Conflicts of Interest}

The authors declare no conflicts of interest regarding the publication of this paper.

\section{References}

Bender, F. (1983). Geology of Burma. Berlin: Gebruder Borntraeger.

Brown, E. T., \& Hoek, E. (1978). Trends in Relationships between Measured Rock in Situ Stresses and Depth. International Journal of Rock Mechanics and Mining Sciences \& Geomechanics, 15, 211-215. https://doi.org/10.1016/0148-9062(78)91227-5

Defant, M. J., \& Drummond, M. S. (1990). Derivation of Some Modern Arc Magmas by Melting of Young Subducted Lithosphere. Nature, 347, 662-665.

https://doi.org/10.1038/347662a0

Eberhardt, E. (2012). The Hoek-Brown Failure Criterion. Rock Mechanics and Rock Engineering, 45, 981-988. https://doi.org/10.1007/s00603-012-0276-4

Hoek, E., \& Brown, E. T. (1980). Underground Excavations in Rock. London: Institution of Mining Metallurgy. https://doi.org/10.1201/9781482288926

Hoek, E., Kaiser, P. K., \& Bawden, W. F. (1993). Support of Underground Excavations in Hard Rock. Vancouver: West Broadway Professional Centre.

Htun, T., Htay, T., \& Zaw, K. (2017). Tin-Tungsten Deposit of Myanmar. Geological Society, 9, 17-54.

Jiang, H., Jiang, S.-Y., Li, W., \& Zhao, K. (2019). Timing and Source of the Hermyingyi W-Sn Deposit in Southern Myanmar, SE Asia: Evidence form Molybdenite Re-Os Age and Sulfur Isotopic Composition. Journal of Earth Science, 30, 69-79.

https://doi.org/10.1007/s12583-018-0860-y

Mitchell, A. H., Chung, S. L., \& Oo, T. (2013). Zircon U-Pb Ages in Myanmar: Magmatic-Metamorphic Events and the Closure of a Neo-Tethys Ocean? Journal of Asian Earth Sciences, 56, 1-23. https://doi.org/10.1016/j.jseaes.2012.04.019

Purwanto, Shimada, H., Takashi, S., Wattimena, R. K., \& Matsui, K. (2013). Influence of Stope Design on Stability of Hanging Wall Decline in Cibaliung Underground Gold Mine. International Journal of Geosciences, 4, 1-8.

https://doi.org/10.4236/ijg.2013.410A001

Sasaoka, T., Takamoto, H., Shimada, H., Oya, J., Hamanaka, A., \& Matsui, K. (2015). Surface Sub-Sidence Due to Underground Mining Operation under Weak Geological in Indonesia. International Journal of Rock Mechanics and Geotechnical Engineering, 7, 337-344. https://doi.org/10.1016/j.jrmge.2015.01.007

Sepehri, M., Apel, D., \& Liu, W. V. (2017). Stope Stability Assessment and Effect of Horizontal to Vertical Stress Ratio on the Yielding and Relaxation Zones around Underground Open Stopes Using Empirical and Finite Element Methods. Archives of Mining Sciences, 62, 653-669. https://doi.org/10.1515/amsc-2017-0047

Yasitli, N. E., \& Unver, B. (2005). 3D Numerical Modelling of Longwall Mining with Top-Coal Caving. International Journal of Rock Mechanics and Mining Science, 42, 219-235. https://doi.org/10.1016/j.ijrmms.2004.08.007 
Zaw, K. (1990). Geological, Petrological and Geochemical Characteristics of Granitoid Rocks in Burma: With Special Reference to the Associated W-Sn Mineralization and Their Tectonic Setting. Journal of Southeast Asia Earth Sciences, 4, 293-335. https://doi.org/10.1016/0743-9547(90)90004-W

Zhao, H., Ma, F., Zhang, Y., \& Guo, J. (2013). Monitoring and Mechanisms of Ground Deformation and Ground Fissures Induced by Cut-and-Fill Mining in the Jinchuan Mine 2, China. Environmental Earth Sciences, 68, 1903-1911.

https://doi.org/10.1007/s12665-012-1877-7 